\title{
Numerical Simulation of Groundwater Recharge from South-to-North Water Division Project
}

\author{
Dasheng Zhang ${ }^{1}$, Yongxiang Zhang ${ }^{1 *}$, Yong Yang ${ }^{2}$, Binghua $\mathrm{Li}^{2}$, Qiang $\mathrm{Li}^{3}$ \\ ${ }^{1}$ College of Architecture and Civil Engineering, Beijing University of Technology, Beijing 100124, China \\ ${ }^{2}$ Beijing Water Science and Technology Institute, Beijing 100089, China \\ ${ }^{3}$ Zhongguancun Sponge City Engineering Research Institute, Beijing 100048, China
}

Corresponding Author Email: yxzhang@bjut.edu.cn

https://doi.org/10.18280/ijht.370123

Received: 18 August 2018

Accepted: 22 December 2018

\section{Keywords:}

water of south-to-north water division project, artificial recharge, numerical simulation, groundwater environment

\begin{abstract}
The purpose of this study was to discuss the change in groundwater level and quantity supplemented to Mihuaishun area from South to North Water Division Project. In this study, the method of numerical simulation was adopted to predict and analysis of the trend of groundwater level in the study area within 20 years. The survey concluded that the cumulative loss of groundwater resources in Mihuaishun area in $2007 \sim 2016$ reaches $-1.784 \times 10^{9} \mathrm{~m}^{3}$. According to the forecast, after the water source of South-to-North Water Division continues to recharge the aquifers at the rate of 0.12 billion $\mathrm{m}^{3} / \mathrm{a}$ for ten years, the local groundwater equilibrium changes from negative to positive, and the water level in the central funnel area increases by $25 \mathrm{~m}$. In addition, the artificial recharge of multiple water sources is also related to local hydrology geological conditions. The impacts of the obtained results are analyzing comprehensively the influence of South to North Water Division supplement on groundwater and providing reference for underground regulation and unified regulation of water resources after the water source of South-to-North Water Division transferred into Beijing.
\end{abstract}

\section{INTRODUCTION}

The essence of artificial recharge of groundwater (also called groundwater recharge) is to artificially inject surface water into underground aquifers by means of some engineering measures to increase underground $[1,2]$. The main purpose of artificial recharge is to alleviate the decrease of groundwater level, store water resources, and protect groundwater of coastal aquifers from seawater intrusion $[3,4]$. The sources of artificial recharge are different, including surface runoff, rainwater, reclaimed water and seawater desalinated water. At the same time, aquifer recharge requires knowledge of different conditions, such as hydrology, and quality of reclaimed water [5]. From the end of the 19th century, the United States has begun research on groundwater artificial storage [6]. In the 1980s, the United States began to implement the Aquifer Storage and Recovery Engineering (ASR) program to carry out manual storage projects in waterdeficient areas [7]. In many European countries, the artificial water storage capacity can reach $10-20 \%$ [8-9]. Since the 1950s, Saudi Arabia has built dams in river valleys to improve the efficiency of floods in the recovery of underground aquifers [10]. Artificial recharge of groundwater has become an important way to improve the utilization of groundwater resources.

With the rapid development of city and industry, the groundwater level decreases year by year due to the overexploitation of groundwater in Beijing. Annual decline of about $0.5-1.0 \mathrm{~m}$ results in land subsidence and a variety of ecological environmental problems [11]. One of the most important underground drinking water sources in Beijing is located in the boundary among Miyun, Huairou and Shunyi Districts, Beijing. In recent years, local groundwater exploitation has caused the decline of the groundwater level from $12 \mathrm{~m}$ to $45 \mathrm{~m}$, forming a huge groundwater funnel.

South-to-North Water Diversion Project diverts water from the Yangtze River to the North China Plain across the region [12]. The South-to-North Water Diversion Project includes the East Route Project, the Middle Route Project and the West Road Project. The total length of the Middle Route Project is $1,230 \mathrm{~km}$. The annual diversion water volume from the upstream of Hanjiang River to the North China Plain reaches 13 billion $\mathrm{m}^{3}$ [13]. After the South-to-North Water Diversion Project diverts water to Beijing, some of the water is used to replenish the Mihuaishun groundwater reservoir and improve the local groundwater environment [14].

On August 21, 2015, the water of South-to-North Water Diversion Project enters the water source of Chaobai River. The water diversion route is from the Lishishan Diversion Gate through the Jingmi Diversion Canal to Xiaozhong River and the junction of the East-to-West Water Diversion, and is transported to Dongmangniu River along the East-to-West Water Diversion, and then to the upstream of the rubber dam of Niulan Mountain of Chaobaihe River via Huaihe River. The total length of the water transportation line is $15 \mathrm{~km}$.

Since the sixties and seventies of the 20th century, numerical simulation has gradually penetrated into hydrogeology and becomes an important method for quantitative evaluation and prediction of groundwater quality and quantity [15-17]. This study simulates and analyzes the changes of local groundwater environment caused by groundwater recharge from the South-to-North Water Diversion Project. The results of simulation and prediction will be helpful to provide theoretical support and technical guidance for multi-source groundwater recharge. 


\section{MATERIALS AND METHODS}

\subsection{Description of the research area}

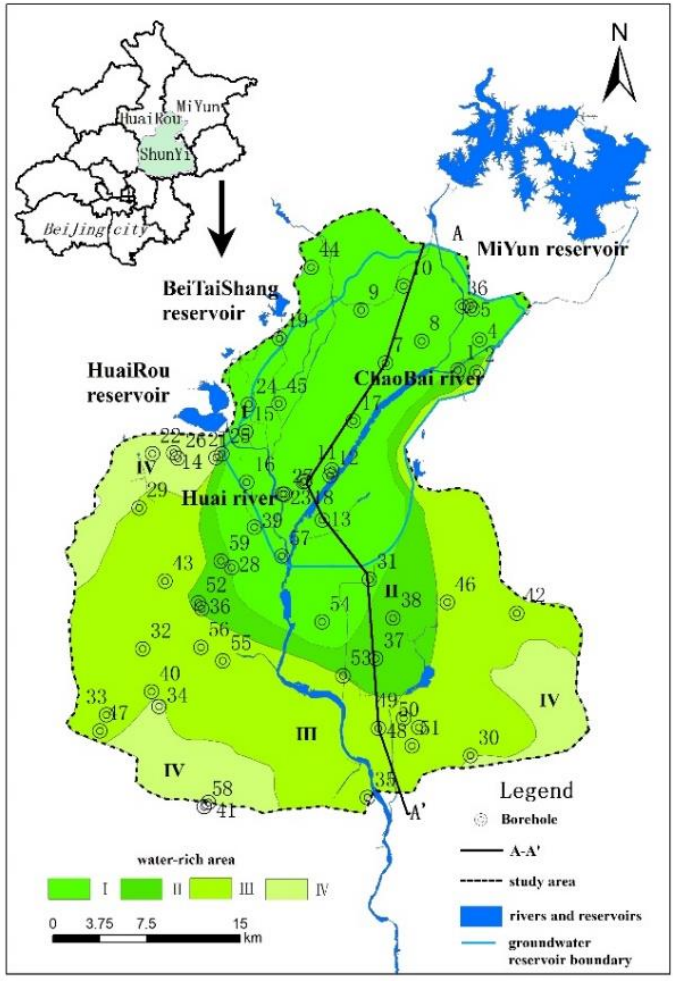

Figure 1. Scope of the Research Area
The research area is located in the northeast of Beijing, including the plain area of Mihuaishun area, belonging to the alluvial fan plain of Chaobai River, with a total area of 1,267 $\mathrm{km}^{2}$. The area of Mihuaishun underground reservoir is 355 $\mathrm{km}^{2}$. The main river in the area is Chaobai River (see Figure 1). According to the water-rich nature of groundwater in the research area, we divide it into four regions by the principle that when the groundwater level of single well drops $3 \mathrm{~m}$, the water output is $>5,000,2,000,5,000,1,000-2,000$ and $<1,000$ $\mathrm{m}^{3} / \mathrm{d}$ respectively.

\subsection{Hydrogeological condition}

From 2007 to 2016, the annual average precipitation in the research area was about $598.3 \mathrm{~mm}$, belonging to temperate continental monsoon climate. The rivers in the research area include Chaohe River, Baihe River, Chaobai River, Mangniuhe River and Huaihe River, which are about $200 \mathrm{~km}$ long. According to the data analysis of 43 holes collected in the previous period (see Figure 1), the hydrogeological characteristics in Mihuaishun area are that the depth of buried bedrock increases from north to south, the thickness of the quaternary strata is between $50 \sim 300 \mathrm{~m}$, and gradually increases from northeast to southwest. The lithology changes from coarse particles to fine particles, and the layers change from a single layer to multiple layers. The quaternary sediments in the study area are widely distributed in plains and mountain valleys. The characteristics of the sedimentary layers are: north thin south thick, east thin west thick. The quaternary strata mainly includes sand pebble layer, sand gravel layer and silty clay layer, as shown in Figure 2.

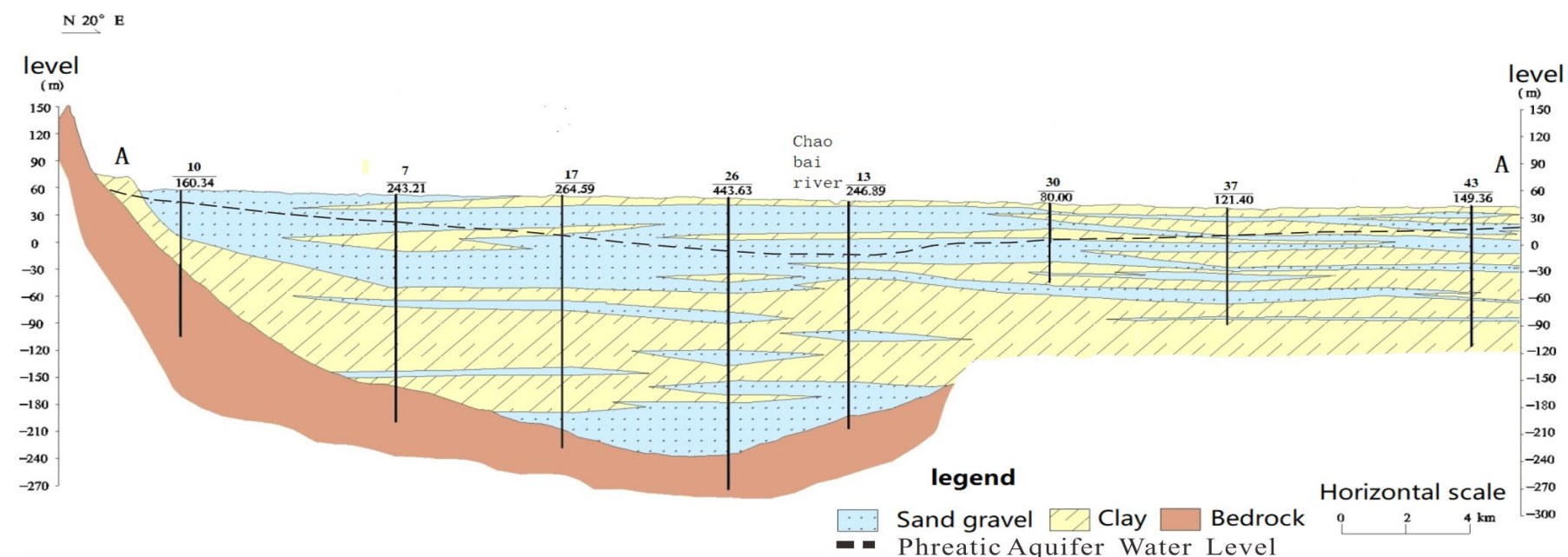

Figure 2. A-A' Hydrogeological section of the research area

\subsection{Recharge water source and groundwater}

\subsubsection{Water source of the South-to-North Water Diversion} Project

The water source of the South-to-North Water Diversion Project is from Beijing section of the Middle Route Project of the South-to-North Water Diversion Project. In 2015 and 2016 , the accumulated water recharge to Chaobai River is 33.79 and 10.34 million $\mathrm{m}^{3}$ respectively, and the total evaporation amount is $500,000 \mathrm{~m}^{3}$. As a result, the total water quantity of infiltrating into the aquifer in the South-to-North Water Diversion Project is 43.63 million $\mathrm{m}^{3}$. 

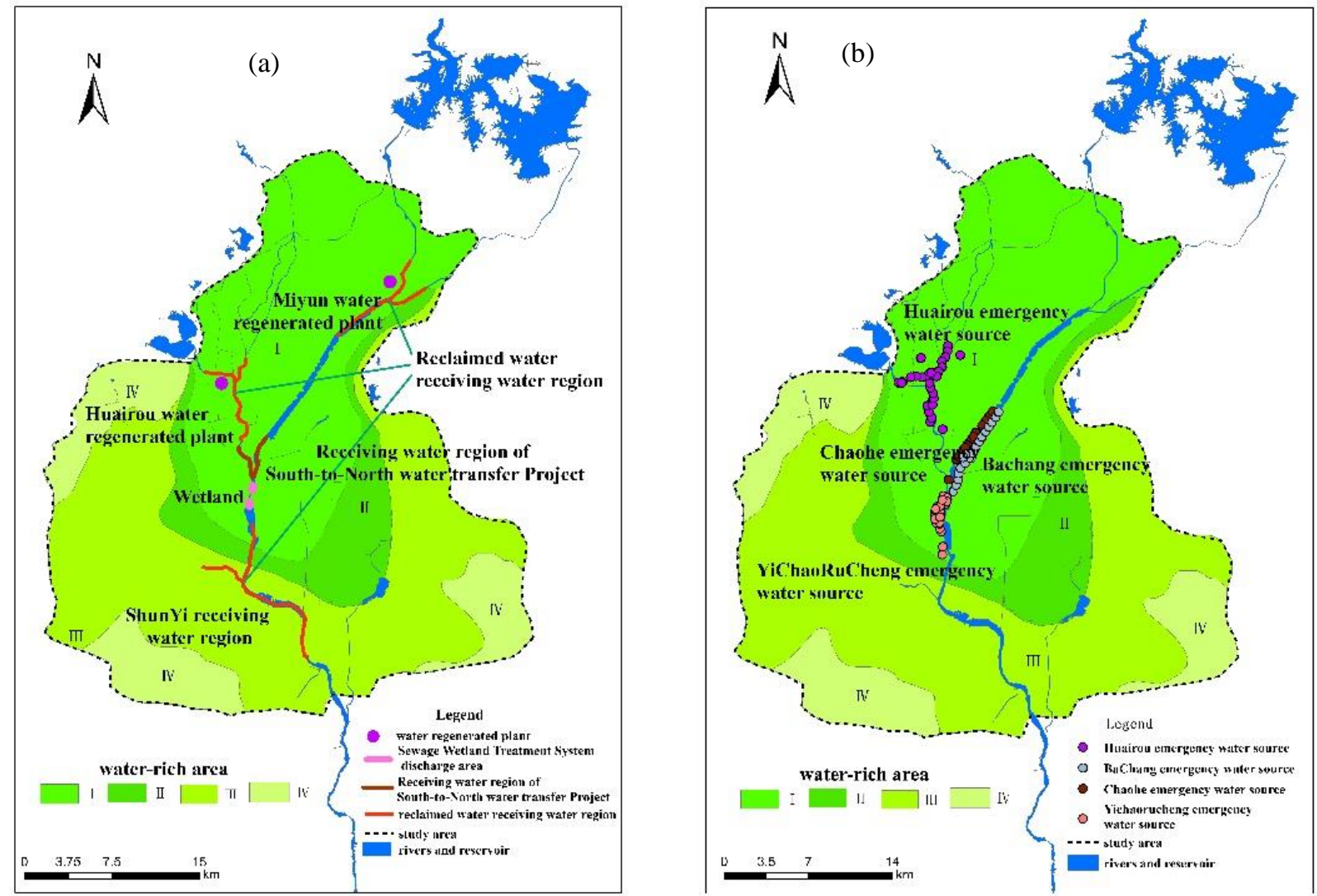

Figure 3. Multi-water source distribution map and position of major groundwater abstractions ((a) The multiple water sources in this research area include water sources from the SNWTP, reclaimed water sources, and a wetland water source, as shown in Figure 3a; (b) We considered four emergency sources of groundwater, which are the major groundwater abstractions as shown in Figure $3 b)$.

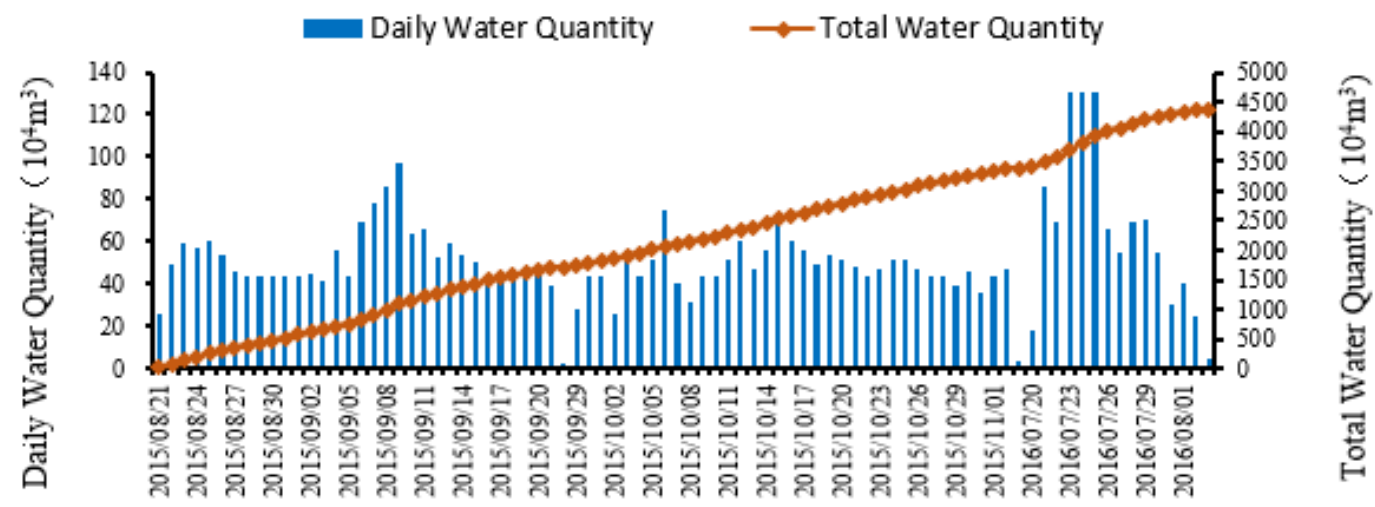

Figure 4. Schematic diagram of water quantity diverted in the South-to-North Water Diversion Project

\subsubsection{Reclaimed water source}

The Chaobai River is almost dry and part of it is recycled into the Chaobai River. The reclaimed water sources include Miyun reclaimed water source, Huairou reclaimed water source and Shunyi reclaimed water source. The infiltration quantity of each reclaimed water source is shown in Table 1.

\subsubsection{Groundwater}

The groundwater in the research area is severely overexploited, forming a huge storage space. According to statistics, since $1999^{[12]}$, the groundwater level has fallen from $12 \mathrm{~m}$ to $45 \mathrm{~m}$, and the accumulated loss of groundwater resources has reached 2.1 billion $\mathrm{m}^{3}$. The continuous lowering of groundwater level weakens the water resources guarantee ability, and the exploitation well of water source nearly reaches the limit of exploitation.

Table 1. Reclaimed water infiltration in Chaobai River from 2007 to 2016

\begin{tabular}{ccc}
\hline & $\begin{array}{c}\text { Cumulative } \\
\text { Emission Capacity } \\
\left(\text { million } \mathbf{m}^{\mathbf{3}}\right)\end{array}$ & $\begin{array}{c}\text { Cumulative } \\
\text { Infiltration Capacity } \\
\left(\mathbf{m i l l i o n} \mathbf{~ m}^{\mathbf{3}}\right)\end{array}$ \\
\hline $\begin{array}{c}\text { Miyun } \\
\text { reclaimed water } \\
\text { Huairou }\end{array}$ & 92 & 76 \\
$\begin{array}{c}\text { reclaimed water } \\
\text { Shunyi }\end{array}$ & 171 & 161 \\
reclaimed water & 179 & 165 \\
Total & 432 & 402 \\
\hline
\end{tabular}




\subsection{Mathematical model}

\subsubsection{Software}

This model uses Feflow software to simulate the groundwater flow model in the research area and solve the equation [18]. The readers can refer to the relevant manuals for the mathematical formula of the software and its numerical solution $[19,20]$. In addition, GIS (ArcView) software is used to pre-process the geological data and hydrogeological data, and the processed data are assigned with values in FEFLOW software. The combination of FEFLOW and GIS (Arc Map) software provides powerful support for solving groundwater problems.

\subsubsection{Flow model}

(1) Model generalization

According to the spatial distribution of stratigraphic and lithologic structures in the research area, the strata in the research area are generalized into seven layers including four aquifers and three aquitards. The aquifers include $30 \mathrm{~m}$ deep phreatic-microconfined aquifer, $50 \mathrm{~m}$ deep aquifer, $80 \mathrm{~m}$ deep aquifer and $150 \mathrm{~m}$ lower aquifer from top to bottom. The bottom boundary of the model is $250 \mathrm{~m}$ at most (see Figure 5 (a)). The research area is divided into triangular elements by using FEFLOW software, and the element discretization is performed on the research area. In this model, it is divided into 59,472 triangular elements and 34,712 nodes. The principle of division is to implement encryption in the watercourse receiving area and groundwater source area, and the periphery is sparse (as shown in Figure 5 (a)). From February 2007 to February 2016, the changes of groundwater level are observed according to the monitoring data collected from 48 wells, as shown in Figure 5 (b).
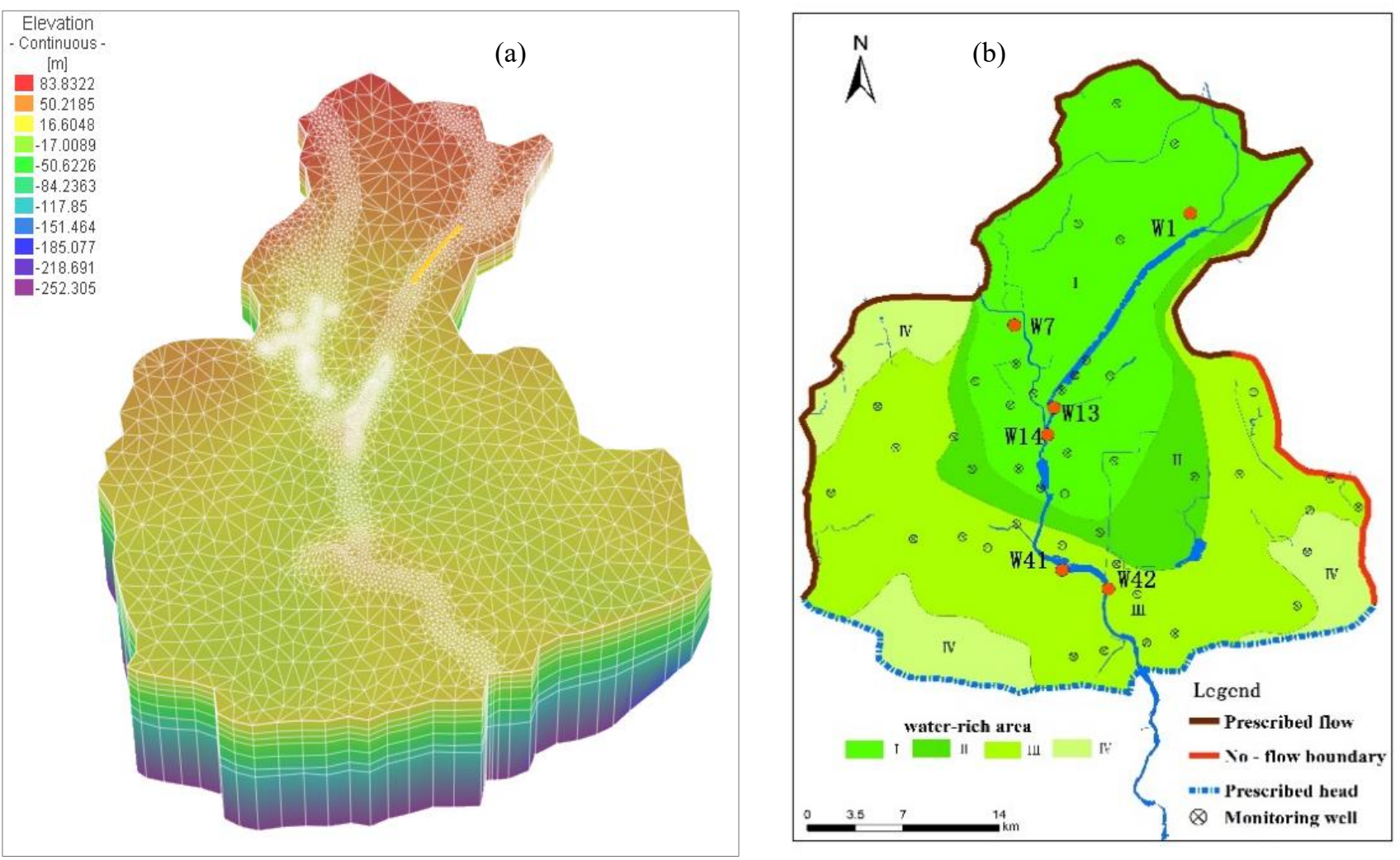

Figure 5. Geological generalization model (a) and boundary conditions (b)

(2) Initial and Boundary Conditions

The model takes the groundwater background water level of the second aquifer as the initial water level in 2007. Under the influence of regional topography, the groundwater flow direction in the research area is mainly from north to south. However, in recent years, due to the massive exploitation of the water source area, a felling funnel has been produced, changing the groundwater flow field (as shown in Figure 10 (a, b)). Here, Figures $10(a, b)$ represent the water levels of the $50 \mathrm{~m}$ aquifer and the $80 \mathrm{~m}$ aquifer in 2007, respectively.

The northern and western regions of the research area is mainly recharged by lateral runoff in front of the mountain, which is regarded as the second inflow boundary under the boundary conditions; the junction between Shunyi and Pinggu is a uplifted mountain, which blocks the hydraulic connection of the quaternary groundwater, and can be regarded as the second type of zero-flow boundary. In that southwest and southeast boundary of the research area, since groundwater level varies slightly, the south boundary is considered as the first class boundary, water head boundary, as shown in Figure 5 (b).

(3) Parameters of Flow Model

According to stratigraphic and lithological data, characteristics of groundwater flow field and characteristics of hydrogeological parameters, the research area is divided into 41 sub-areas (as shown in Figure 6), and the parameters include hydraulic conductivity $(\mathrm{K})$ and water supply $(\mu)$. According to borehole monitoring data, take $\mathrm{K}$ value between $6.5 \sim 106.5 \mathrm{~m}$ /day and $\mu$ value between $0.01 \sim 0.24$.

(4) Source and Sink Items

Taking 2007 as the starting year, according to the recharge, runoff and discharge conditions of groundwater in the research area, the water quantity of each source and sink item is calculated as shown in Table 2. 


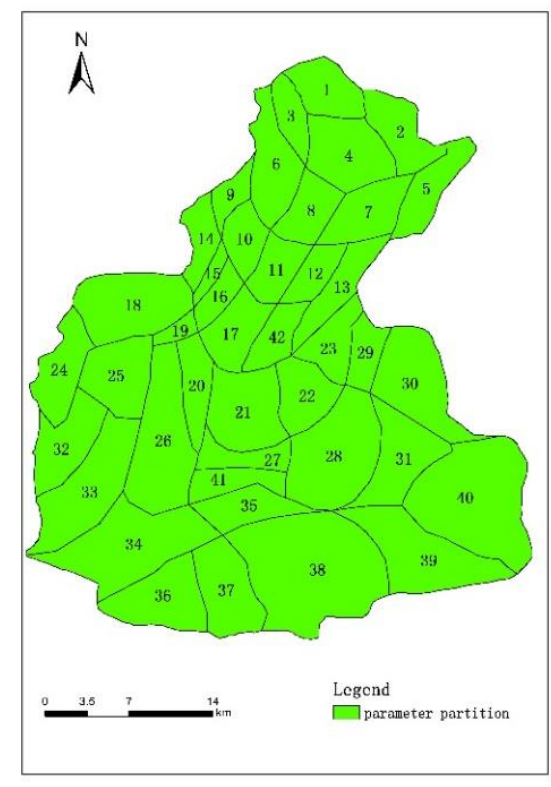

Figure 6. Parameter partition map

Table 2. Water quantity statistics of each source and sink item

\begin{tabular}{cccc}
\hline $\begin{array}{c}\text { Recharge } \\
\text { Condition }\end{array}$ & $\begin{array}{c}\text { Volume } \\
\left(\times \mathbf{1 0}^{6} \mathbf{m}^{\mathbf{3}}\right)\end{array}$ & $\begin{array}{c}\text { Discharge } \\
\text { Condition }\end{array}$ & $\begin{array}{c}\text { Volume } \\
\left(\times \mathbf{1 0}^{6} \mathbf{m}^{\mathbf{3}}\right)\end{array}$ \\
\hline $\begin{array}{c}\text { Precipitation } \\
\text { Infiltration }\end{array}$ & 2159 & Evaporation & Negligible \\
$\begin{array}{c}\text { Agricultural } \\
\text { Irrigation }\end{array}$ & 330 & Exploitation & 5375 \\
$\begin{array}{c}\text { Infiltration } \\
\text { River Leakage } \\
\text { Total }\end{array}$ & $\begin{array}{c}402 \\
2891\end{array}$ & Total & 5375 \\
\hline
\end{tabular}

In Table 2, the rainfall infiltration amount can be calculated by Formula (1):

$Q_{j}=\alpha \times F \times X$

where, $Q_{j}$ is rainfall infiltration amount, $\left(\mathrm{m}^{3} / \mathrm{a}\right) ; \alpha$ is annual rainfall infiltration coefficient; $F$ is calculated area $\left(\mathrm{m}^{2}\right)$; and $X$ is annual rainfall amount $(\mathrm{m} / \mathrm{a})$.

The agricultural irrigation regression can be calculated by Formula (2):

$Q=Q_{g} \times \beta$

where, $Q$ is agricultural irrigation regression, $\left(\mathrm{m}^{3} / \mathrm{a}\right) ; Q_{g}$ is agricultural production, $\left(\mathrm{m}^{3} / \mathrm{a}\right)$; and $\beta$ is irrigation regression coefficient.

The recharge of lateral inflow can be estimated using the equation (3)

$Q_{c}=K \times M \times I \times L$

where, $Q_{c}$ is recharge of lateral inflow, $\left(\mathrm{m}^{3} / \mathrm{a}\right) ; \mathrm{K}$ is aquifer permeability coefficient, $\left(\mathrm{m}^{3} / \mathrm{s}\right)$; $\mathrm{M}$ is aquifer thickness, $(\mathrm{m})$; I is groundwater hydraulic gradient; $\mathrm{L}$ is the length of the aquifer on the boundary, $(\mathrm{m})$.

(5) Model Calibration and Validation

The aim of the calibration phase is to make the simulation data of the model consistent with the field data by adjusting the parameters. In this study, 48 wells are used to calibrate the model results. The calibration phase of the model is from January 2007 to December 2014. The model parameters that have been calibrated in this process include the hydraulic conductivity $(\mathrm{K})$ and the water supply $(\mu)$. The duration is 30 days. Table 3 shows the results of calibrating water flow model parameters. The validation period of the model is from January 1, 2014 to December 30, 2016. As shown in Figure 7, by comparing the observed value of the groundwater level at the end of 2016 with the simulated value, it can be seen that the observed value matches the simulated value with a high degree.

Table 3. Calibration table for parameters of phreatic aquifer (where the value in " () " is the initial value of parameters before calibration)

\begin{tabular}{|c|c|c|c|c|c|}
\hline $\begin{array}{l}\text { Partition } \\
\text { Number }\end{array}$ & $\begin{array}{c}\mathbf{K} \\
(\mathbf{m} / \mathbf{d})\end{array}$ & $\boldsymbol{\mu}$ & $\begin{array}{l}\text { Partition } \\
\text { Number }\end{array}$ & $\begin{array}{c}\mathbf{K} \\
(\mathbf{m} / \mathbf{d})\end{array}$ & $\boldsymbol{\mu}$ \\
\hline 1 & $\begin{array}{c}5.2 \\
(5.2)\end{array}$ & $\begin{array}{c}0.010 \\
(0.080)\end{array}$ & 22 & $\begin{array}{c}60.0 \\
(62.6)\end{array}$ & $\begin{array}{c}0.180 \\
(0.190)\end{array}$ \\
\hline 2 & $\begin{array}{c}105.0 \\
(106.5)\end{array}$ & $\begin{array}{c}0.250 \\
(0.240)\end{array}$ & 23 & $\begin{array}{c}40.0 \\
(38.0)\end{array}$ & $\begin{array}{c}0.150 \\
(0.130)\end{array}$ \\
\hline 3 & $\begin{array}{c}100.0 \\
(104.3)\end{array}$ & $\begin{array}{c}0.250 \\
(0.240)\end{array}$ & 24 & $\begin{array}{c}30.0 \\
(28.0)\end{array}$ & $\begin{array}{c}0.100 \\
(0.120)\end{array}$ \\
\hline 4 & $\begin{array}{c}100.0 \\
(102.0)\end{array}$ & $\begin{array}{c}0.250 \\
(0.240)\end{array}$ & 25 & $\begin{array}{c}25.0 \\
(20.0)\end{array}$ & $\begin{array}{c}0.100 \\
(0.100)\end{array}$ \\
\hline 5 & $\begin{array}{c}80.0 \\
(73.0)\end{array}$ & $\begin{array}{c}0.250 \\
(0.240)\end{array}$ & 26 & $\begin{array}{c}20.0 \\
(15.2)\end{array}$ & $\begin{array}{c}0.100 \\
(0.130)\end{array}$ \\
\hline 6 & $\begin{array}{c}90.0 \\
(91.3)\end{array}$ & $\begin{array}{c}0.250 \\
(0.230)\end{array}$ & 27 & $\begin{array}{c}20.0 \\
(20.5)\end{array}$ & $\begin{array}{c}0.120 \\
(0.140)\end{array}$ \\
\hline 7 & $\begin{array}{c}90.0 \\
(88.2)\end{array}$ & $\begin{array}{c}0.250 \\
(0.220)\end{array}$ & 28 & $\begin{array}{c}15.0 \\
(13.0)\end{array}$ & $\begin{array}{c}0.120 \\
(0.140)\end{array}$ \\
\hline 8 & $\begin{array}{c}85.5 \\
(88.5)\end{array}$ & $\begin{array}{c}0.250 \\
(0.220)\end{array}$ & 29 & $\begin{array}{c}20.0 \\
(30.6)\end{array}$ & $\begin{array}{c}0.120 \\
(0.160)\end{array}$ \\
\hline 9 & $\begin{array}{c}70.0 \\
(59.6)\end{array}$ & $\begin{array}{c}0.200 \\
(0.210)\end{array}$ & 30 & $\begin{array}{c}20.0 \\
(14.5)\end{array}$ & $\begin{array}{c}0.080 \\
(0.080)\end{array}$ \\
\hline 10 & $\begin{array}{c}75.5 \\
(75.5)\end{array}$ & $\begin{array}{c}0.200 \\
(0.210)\end{array}$ & 31 & $\begin{array}{c}15.0 \\
(12.6)\end{array}$ & $\begin{array}{c}0.080 \\
(0.060)\end{array}$ \\
\hline 11 & $\begin{array}{c}70.5 \\
(73.3)\end{array}$ & $\begin{array}{c}0.200 \\
(0.210)\end{array}$ & 32 & $\begin{array}{c}12.0 \\
(12.3)\end{array}$ & $\begin{array}{c}0.080 \\
(0.060)\end{array}$ \\
\hline 12 & $\begin{array}{c}70.5 \\
(76.5)\end{array}$ & $\begin{array}{c}0.200 \\
(0.210)\end{array}$ & 33 & $\begin{array}{l}10.0 \\
(8.5)\end{array}$ & $\begin{array}{c}0.050 \\
(0.050)\end{array}$ \\
\hline 13 & $\begin{array}{c}60.0 \\
(58.2)\end{array}$ & $\begin{array}{c}0.200 \\
(0.200)\end{array}$ & 34 & $\begin{array}{l}10.0 \\
(8.9)\end{array}$ & $\begin{array}{c}0.010 \\
(0.013)\end{array}$ \\
\hline 14 & $\begin{array}{c}60.0 \\
(51.5)\end{array}$ & $\begin{array}{c}0.200 \\
(0.200)\end{array}$ & 35 & $\begin{array}{c}11.0 \\
(11.0)\end{array}$ & $\begin{array}{c}0.010 \\
(0.016)\end{array}$ \\
\hline 15 & $\begin{array}{c}50.0 \\
(51.2)\end{array}$ & $\begin{array}{c}0.150 \\
(0.180)\end{array}$ & 36 & $\begin{array}{l}10.0 \\
(7.6)\end{array}$ & $\begin{array}{c}0.015 \\
(0.010)\end{array}$ \\
\hline 16 & $\begin{array}{c}60.5 \\
(65.5)\end{array}$ & $\begin{array}{c}0.150 \\
(0.190)\end{array}$ & 37 & $\begin{array}{c}8.0 \\
(9.5)\end{array}$ & $\begin{array}{c}0.015 \\
(0.010)\end{array}$ \\
\hline 17 & $\begin{array}{c}60.5 \\
(60.5)\end{array}$ & $\begin{array}{l}0.150 \\
(0.190)\end{array}$ & 38 & $\begin{array}{l}15.0 \\
(20.5)\end{array}$ & $\begin{array}{c}0.040 \\
(0.030)\end{array}$ \\
\hline 18 & $\begin{array}{c}50.0 \\
(38.5)\end{array}$ & $\begin{array}{c}0.150 \\
(0.130)\end{array}$ & 39 & $\begin{array}{c}8.0 \\
(10.3)\end{array}$ & $\begin{array}{c}0.010 \\
(0.010)\end{array}$ \\
\hline 19 & $\begin{array}{c}50.0 \\
(52.2)\end{array}$ & $\begin{array}{c}0.150 \\
(0.110)\end{array}$ & 40 & $\begin{array}{c}5.0 \\
(5.0)\end{array}$ & $\begin{array}{c}0.015 \\
(0.010)\end{array}$ \\
\hline 20 & $\begin{array}{c}55.0 \\
(62.6)\end{array}$ & $\begin{array}{c}0.180 \\
(0.200)\end{array}$ & 41 & $\begin{array}{c}5.0 \\
(5.0)\end{array}$ & $\begin{array}{c}0.030 \\
(0.040)\end{array}$ \\
\hline 21 & $\begin{array}{c}55.0 \\
(62.8)\end{array}$ & $\begin{array}{c}0.180 \\
(0.200)\end{array}$ & & & \\
\hline
\end{tabular}

The main objective of the calibration stage is to obtain results as much as possible in agreement with the field data by acting on the variables which characterize the system. The results of this calibration are shown in Figure 8, which shows the good fit between measurements and calculations in the 48 observation wells inside the modelled area. Two sets of values are highly correlated and plot very close to the perfect correspondence line. The average absolute difference is about $1.50 \mathrm{~m}$, so this is a highly satisfactory value. 

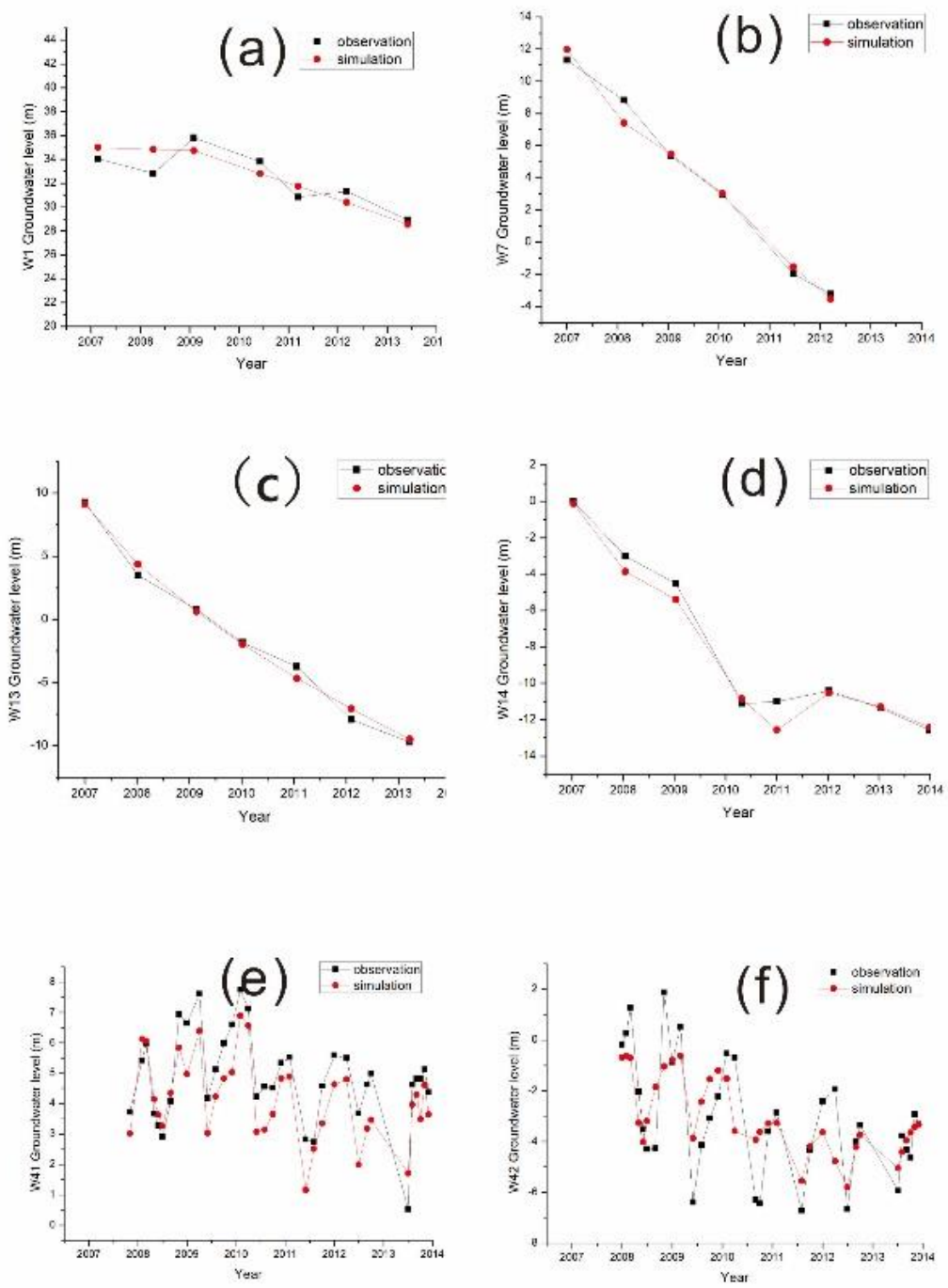

Figure 7. Comparison of observed and simulated values of groundwater level for a typical monitoring well near a river (as shown in Figure $5(b))$

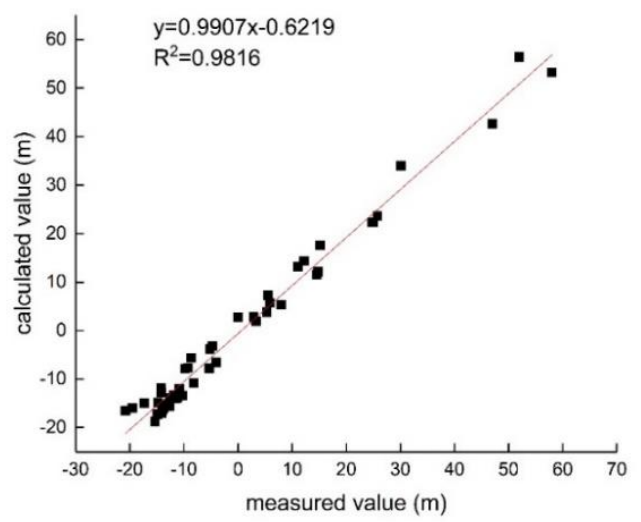

Figure 8. calibration curve (comparison is made with December 2016 values for 48 observation wells)

\subsection{Water equilibrium analysis}

According to the recharge and discharge situation of the model in the research area, the groundwater resource loss and accumulated loss in the research area from 2007 to 2016 are analyzed, as shown in Table 4. As can be seen from the table, the accumulated loss of underground water resources in Mihuaishun water source area is 1.75 billion m3 from 2007 to 2016. After the water from the South-to-North Water Diversion Project enters Beijing, water exploitation in Huairou emergency water source area is reduced, and the annual loss of groundwater resources is significantly reduced by groundwater recharge of the South-to-North Water Diversion to the south of the channel before the rubber dam in Niulan Mountain, but in general, groundwater in the research area is in negative equilibrium and groundwater supply is less than drainage, so the storage resources of groundwater are largely consumed.

Table 4. Loss of groundwater resources from 2007 to 2016

\begin{tabular}{ccc}
\hline Items & $\begin{array}{c}\text { Discharge } \\
\text { Condition }\end{array}$ & $\begin{array}{c}\text { Recharge } \\
\left.\text { Condition } \mathbf{( m}^{\mathbf{3}}\right)\end{array}$ \\
\hline boundary condition & $7.56 \mathrm{e}+08$ & $1.45 \mathrm{e}+09$ \\
Exploitation & $5.37 \mathrm{e}+09$ & 0 \\
River Leakage & 0 & $4.39 \mathrm{e}+08$ \\
Precipitation Infiltration & & \\
and Agricultural & & \\
Irrigation Infiltration & 0 & $2.49 \mathrm{e}+09$ \\
Evaporation & 0 & 0 \\
Total & $6.13 \mathrm{e}+09$ & $4.38 \mathrm{e}+09$ \\
\hline
\end{tabular}




\subsection{Model prediction}

The forecast period is 2017 2026. The annual infiltration amount of the South-to-North Water Diversion Project is 120 million $\mathrm{m}^{3}$. The annual rainfall during the forecast period is calculated according to the annual rainfall of $567 \mathrm{~mm}$. The rest conditions remain unchanged.

\section{RESULTS AND DISCUSSION}

\subsection{Prediction results and analysis of flow models}

Select typical monitoring wells to predict changes of the groundwater level (as shown in Figure 9), which shows that the groundwater level in the receiving area of South-to-North Water Diversion continues to rise rapidly. With the increase of water diversion time, the rising rate of groundwater level slows down rapidly. After 10 years, the rise in the water level of W13 monitoring well can reach about $25 \mathrm{~m}$. The water level of W14 monitoring well in the wetland area is obviously influenced by the water recharge of the South-to-North Water Diversion Project. The groundwater level continues to rise, and may rise about $15 \mathrm{~m}$ after 10 years. The rise in the water level of W41 monitoring well is obvious and the rise in the water level of W42 monitoring well level is less in Shunyi reclaimed water receiving area, which show that the groundwater level in the north of Shunyi reclaimed water receiving area rises obviously and that in the south does not change greatly.

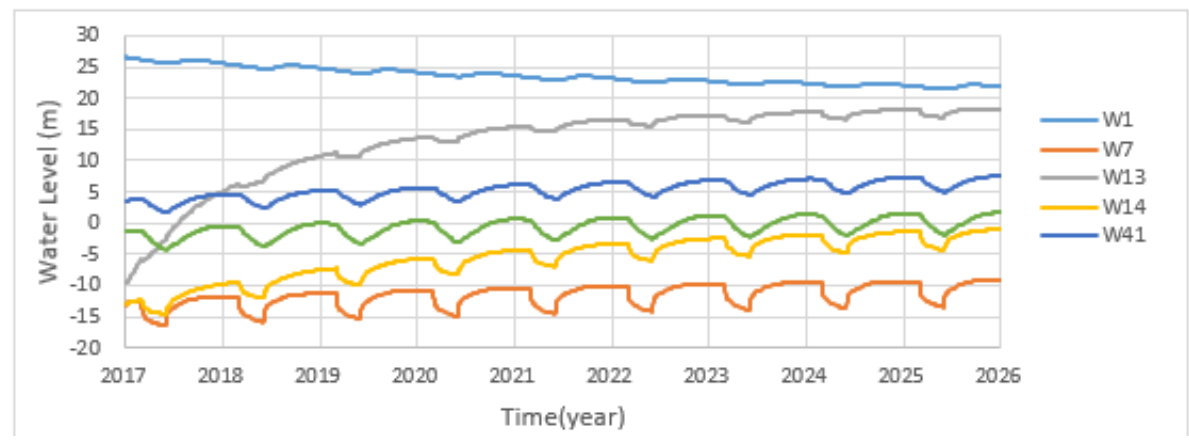

Figure 9. Groundwater level prediction curve for some typical monitoring wells
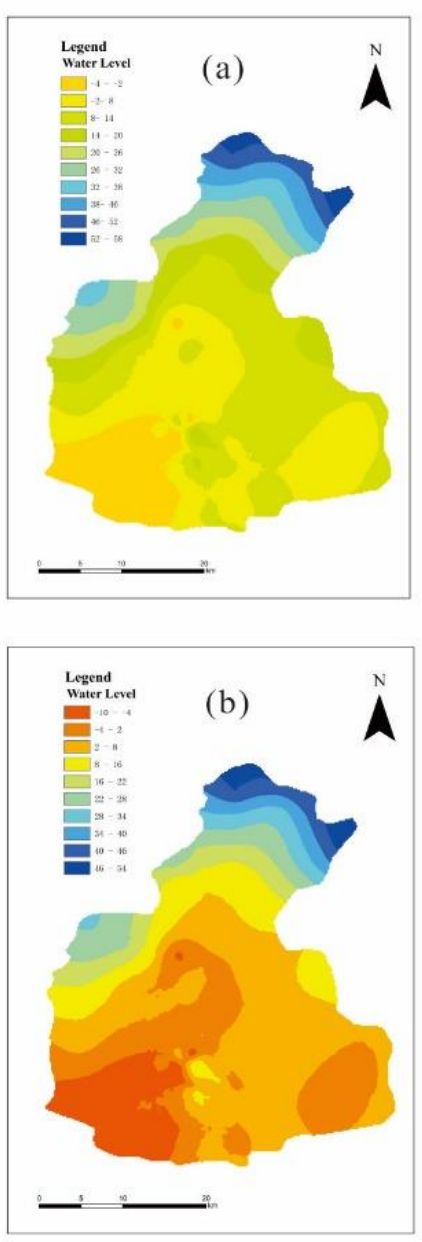
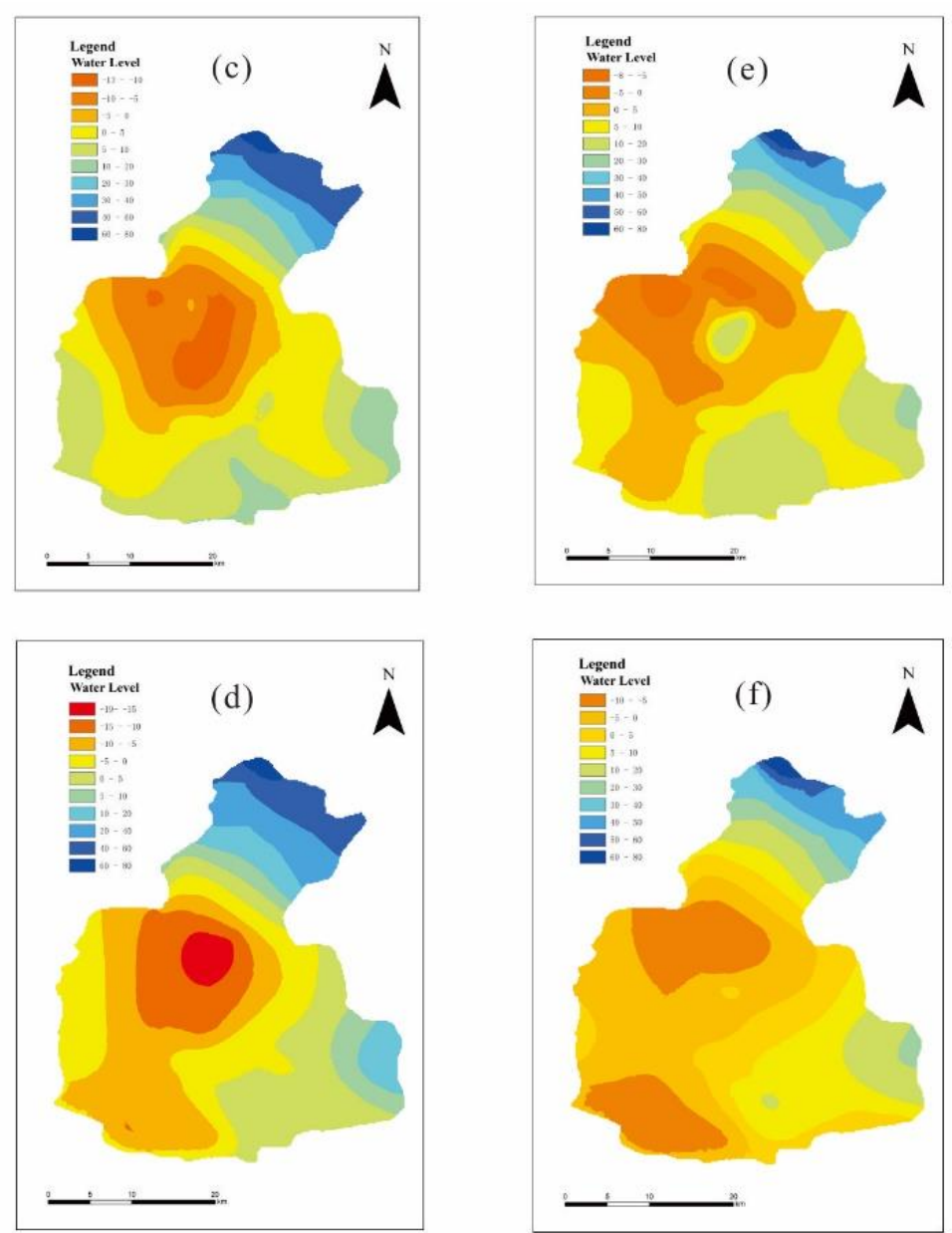

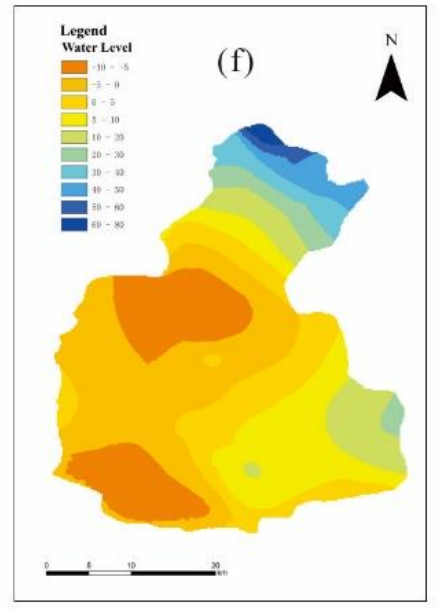

Figure 10. Contour map of groundwater level. (a, b), (c, d) and (e, f) represent the water levels of the $50 \mathrm{~m}$ aquifer and the $80 \mathrm{~m}$ aquifer in 2007, 2016 and 2026, respectively) 
During the continuous recharge process, the groundwater hillock continues to spread to the periphery. The groundwater level in the northern part of Shunyi reclaimed water receiving area rises obviously, but the groundwater level in the southern part changes little.

The results show that the regional groundwater resources change from negative equilibrium to positive equilibrium since the annual amount of underground water recharge from the South-to-North Water Diversion Project is 120 million $\mathrm{m}^{3}$ (as shown in Figure $10(\mathrm{e}, \mathrm{f})$ ). The groundwater level has changed from a decline trend before 2016 to a continuous rise, and the groundwater level around the water -receiving channel rises rapidly, forming a $27.38 \mathrm{~km}^{2}$ groundwater hillock surrounded by a $5 \mathrm{~m}$ contour. During the continuous recharge process, the groundwater hillock continues to spread to the periphery. The groundwater level on both sides of the Chaobai River in the southern Shunyi area rises slightly.

\section{CONCLUSIONS}

This study establishes a numerical model for groundwater recharge from the South-to-North Water Diversion Project. The model can be used to calculate the variation trend of the water level caused by such recharge in the research area. The study shows that the water from South-to-North water diversion contributes to groundwater recharge, raises groundwater level and increases groundwater reserves. From 2007 to 2016, the accumulated loss of groundwater resources in Mihuaishun area reached $-1.75 \times 10^{9} \mathrm{~m}^{3}$. The results of model prediction show that after 10 years of water recharge from the water source of the South-to-North Water Diversion Project to the aquifer at the rate of 1.2 billion $\mathrm{m}^{3} / \mathrm{a}$, the local groundwater equilibrium becomes positive from negative, and the water level in the central funnel area increases by $25 \mathrm{~m}$. In addition, the artificial recharge of multiple water sources is also related to local hydrogeological conditions. The aquifer in the north of the research area is a single sand -pebble layer, and the hydraulic connection in the north area is better than that in the south area. Therefore, the long-term recharge makes the groundwater level difference between the water supply area and the reclaimed water supply area of the South-to-North Water Diversion Project reduced, and the flow rate of reclaimed water to the central funnel area smaller. Therefore, it is suggested to increase the diversion of the South-to-North Water Diversion Project.

\section{ACKNOWLEDGMENTS}

Partial support for this study came from the National Key Research and Development Program (2016YFC0401404) and the Beijing Municipal Science and Technology Commission Project (K2004018201601). Special thanks are given to teacher Wu Jin and Huang Xuezheng and student Guo Wenjun.

\section{REFRENCES}

[1] Bouwer H. (2002). Artificial recharge of groundwater: Hydrogeology and engineering. Hydrogeology Journal 10(1): 121-142. https://doi.org/10.1007/s10040-0010182-4
[2] Scanlon BR, Keese KE, Flint AL, Flint LE, Gaye CB, Edmunds WM. (2006). Global synthesis of groundwater recharge in semiarid and arid regions. Hydrological Processes 20(15): https://doi.org/10.1002/hyp.6335

[3] Asano T, Cotruvo JA. (2004). Groundwater recharge with reclaimed municipal wastewater: Health and regulatory considerations. Water Research 38(8): 19411951. https://doi.org/10.1016/j.watres.2004.01.023

[4] Scanlon BR, Keese KE, Flint AL, Flint LE, Gaye CB, Edmunds WM. (2006). Global synthesis of groundwater recharge in semiarid and arid regions. Hydrological Processes 20(15):

https://doi.org/10.1002/hyp.6335

[5] Vandenbohede A, Houtte EV. (2012). Heat transport and temperature distribution during managed artificial recharge with surface ponds. Journal of Hydrology 472 473(4): 77-89. https://doi.org/10.1016/j.jhydrol.2012.09.028

[6] Reilly TE, Harbaugh AW. (2010). Simulation of cylindrical flow to a well using the U.S. geological survey modular finite-difference ground-water flow model. Groundwater 31(3): 489-494. https://doi.org/10.1111/j.1745-6584.1993.tb01851.x

[7] Job C. (2012). Water treatment practices at groundwatersupplied community water systems in the united states. Groundwater Monitoring and Remediation 32(1): 35-36. https://doi.org/10.1111/j.1745-6592.2011.01381.x

[8] Schmidt CM, Fisher AT, Racz AJ, Lockwood BS, Huertos ML. (2011). Linking denitrification and infiltration rates during managed groundwater recharge. Environmental Science and Technology 45(22): 96349640. https://doi.org/10.1021/es2023626

[9] Martinez-Santos P, Martinez-Alfaro P, Murillo JM. (2005). A method to estimate the artificial recharge capacity of the crestatx aquifer (majorca, spain). Environmental Geology 47(8): 1155-1161. https://doi.org/10.1007/s00254-005-1259-5

[10] Mylopoulos N, Mylopoulos Y, Tolikas D, Veranis N. (2007). Groundwater modeling and management in a complex lake-aquifer system. Water Resources Management 21(2): 469-494. https://doi.org/10.1007/s11269-006-9025-3

[11] Duan W. (2005). Beijing water resources and the south to north water diversion project. Revue Canadienne De Génie Civil 32(1): 159-163. https://doi.org/10.1139/104113

[12] Li S, Li J, Zhang Q. (2011). Water quality assessment in the rivers along the water conveyance system of the middle route of the south to north water transfer project (china) using multivariate statistical techniques and receptor modeling. Journal of Hazardous Materials 195: 306-317. https://doi.org/10.1016/j.jhazmat.2011.08.043

[13] Wei S, Yang H, Abbaspour K, Mousavi J, Gnauck A (2010). Game theory based models to analyze water conflicts in the middle route of the south-to-north water transfer project in china. Water Research 44(8): 24992516. https://doi.org/10.1016/j.watres.2010.01.021

[14] Liu LC. (2003). Giving full play to the ecological benefits of the south to North Water Transfer Remediation of groundwater in the North China Plain. South to North Water Transfer and Water Conservancy Science and Technology 1(1): 17-19. https://doi.org/10.3969/j.issn.1672-1683.2003.01.005 
[15] Elmansour AA, Elseed EG. (2018). Groundwater dynamics in Ennuhud Basin, Kordofan Region, Sudan. Environmental and Earth Sciences Research Journal 5(4): 94-100. https://doi.org/10.18280/eesrj.050403

[16] Sufi AB, Latif M, Skogerboe GV. (1998). Simulating skimming well techniques for sustainable exploitation of groundwater. Irrigation and Drainage Systems 12(3): 203-226. https://doi.org/10.1023/a:1006085700543

[17] Konikow LF. (1981). Role of numerical simulation in analysis of ground-water quality problems. Studies in
Environmental Science 21(1760): 299-312. https://doi.org/10.1016/0048-9697(81)90163-7

[18] Diersch H. (2009). FEFLOW: finite element subsurface flow and transport simulation system. Reference Manual. WASY, Berlin, pp. 292.

[19] Diersch H. (1998a). Reference manual FEFLOW. Institute for Water Resources Planning and Systems Research, WASY, Berlin.

[20] Diersch H. (1998b) FEFLOW: User's manual. Institute for Water Resources Planning and Systems, WASY, Berlin. 